\title{
Literary work of a surgeon
}

\author{
Radu Mirela', Réka Incze (Kutasi)² \\ ${ }^{1}$ Faculty of Medicine, "Titu Maiorescu" University of Bucharest, Romania \\ ${ }^{2}$ Faculty of Medicine, Tg. Mures University of Medicine and Pharmacy, Tg. Mures, Romania
}

\begin{abstract}
Osborne Henry Mavor was a complex figure of the Scottish culture being able to dedicate his youth years to medicine and the middle age to writing plays. He served in the Royal Army Medical Corps during World War I and for other six years he served in Middle East, India, Persia, Baku and Constantinople. All his experiences in these exotic countries helped him gather the material for his future plays. These locations inspired him with legends, superstitions and biblical knowledge. Public recognition came after his first play, in 1928. Six years later he dropped practicing medicine and devoted all his energy to writing literature although he came back to his first passion during World War II serving on a Hospital Ship in Norway. He supported culture as much as he could by setting up Glasgow Citizens' Theatre (1943), College of Drama in Glasgow (1950), reaching to be the director of The Scottish National Theatre Society. He contributed not only to the development of Scottish theatre but by encouraging new talented playwrights.
\end{abstract}

Keywords: surgeon, playwright, drama, apocryphal texts, mystery

The Scottish surgeon Osborne Henry Mavor (1888-1951) proved he could blend the practice of medicine with writing, becoming "a notable figure in modern British drama" (1). After graduating from the Faculty of Medicine in Glasgow, Mavor worked as a surgeon in World War I. After the war, the dramaturgic activity his started under the pseudonym James Bridie (James taken from the grandfather's name and Bridie from the name of his grandmother's family).

In 1938 he gave up medicine in order to devote himself to writing. However, medically he contributed to World War II. He lost his elder son during this conflagration. In 1943, together with two friends, Mavor set up the Citizens Theater in Glasgow. In 1950 he founded the Dramatic College of the Scottish Royal Academy of Music. The writer's talent made him work in the post-war years with Alfred Hitchcock. The first of three films, The Paradine Case (1947), was written by the physician-playwright but it was rewritten by producer David O. Selznick, who binds his name to another famous film: Gone with the Wind. The film is a combination of detective action, murder and love affair. In 1949, Under Capricorn, movie whose action is based in Australia, is the same recipe: a crime and a love triangle. The third film for which the doctor wrote the dialogues is Stage Fright (1950) and repeats the idea of mystery, murder and love.

Although since his medical studies he wrote poetry, his literary debut came in 1928 when he wrote the first theatre drama: Sunlight Sonata (comedy of seven characters affected by the seven capital sins) written under the pseudonym Mary Henderson. The following year he wrote two more plays: The Switchback (on medical ethics) and What it is to be young. In 1930, the two plays signed by the physician are put on stage under the titles: The Anatomist and Tobias and the Angel. The Anatomist is based on a real fact: the anatomist, anthropologist and zoologist Robert Knox (1791-1862) is known in the history of medicine for the theory of philosophic anatomy seeking to discover perfect patterns and common structures in all existing organisms in nature but he is to be remembered more for the involvement in 16 cases of murder committed by William Burke and William Hare in Edinburgh who provided the physician with the corpses for dissections. Although respected historical truth, Mavor's character is purely fictional and: "has a large element of tragedy and melodrama, but the 
beginning and end seem to indicate that the play is some sort of comedy - a serious, exciting, thoughtful comedy, full of ideas and arguments, containing horror but somehow managing not to leave that as the final impression" (2).

Birdie's story covers a wide range of issues: the scientific need to make dissections against religious dogmatism, a crisis of consciousness on a social background depicting life in the notorious suburbs, and the play builds an imaginary character that blends the grotesque with the sublime because Knox is in Birdie's play a character made up of lights and shadows, cunning but good teacher and anatomist, ironic but soulful: "Mavor was able to weave together historical fact and fantasy around the compelling figure of Dr. Knox, the man of science who has to go to extreme criminal lengths in his pursuit of knowledge" (3). The duplicitous nature of the character, made up of defeatism combined with sarcasm, obsessive behavior mixed with ironical tone, is what attracted the attention of critics. This bizarre construction, and not the story itself, is what proposes the author of the play as a renowned playwright: "His characters toss ideas about, playfully or skeptically or seriously; and often the drama is set in motion through a contrast or opposition between a mocking or reductive spirit and some character who is possessed and obsessed by some new idea pointing to the future" (2). The struggle between good and evil is the central theme of Tobias and the Angel, a text based on an apocryphal scripture text. The play is loaded with symbols: Tobias's father's blindness, Tobias's initiatory journey to Persia, and Raphael - the angel that accompanies and guides the young man, swimming across the Tibris River. Reaching the destination, Tobias falls in love with Sara, a girl who was courted by a demon, Asmodeus, who killed any potential rival. The three succeed in defeating the demon and return to Tobias's father, Tobit, whom he heals of blindness.

In 1933, Bridie published a play in two acts A Sleeping Clergyman. The theme of this play is "hereditary wickedness in a medical family and the ultimate triumph of the will over genetic evil" (3). This play has two main themes favorite to the author: that of the scientist and the religious one - of man's relationship with divinity. The action includes physicists: Dr. Cooper, a gynecologist, and Dr. Coutts, a neurologist, who talk about the recent funeral which the latter attended. At Dr. Marshall's funeral, we learn from Coutts, shows up another physician character: bacteriologist Charles Cameron. The play focuses on Cameron's family, the sto- ry tells the fate of three generations over seventy years (between 1867 and 1930). The first generation is represented by a young doctor, researcher, suffering from tuberculosis who has an illegitimate little girl (Wilhelmina) with Harriet Marshall. The young man dies before he recognizes his child. The second generation, Wilhelmina becomes pregnant with a young man of modest condition. Proposed by a wealthy man, the girl reaches to poison her boyfriend. The third generation is represented by the young who showed up at the funeral, a bacteriologist who finds cure for the plague.

Feeling more and more inspired, Bridie continued to write fervently, signing other plays: Mary Read the story of a nonconformist, pirate (1934), Susannah and the Elders, a play of religious inspiration (1935). The year 1938 when the author decided to give up medicine in favor of dramaturgy, was an extremely prolific one because the physician managed to write not less than five dramas: The King of Nowhere, Babes in the Wood, The Last Trump (the story of an influential businessman become hypochondriac), The Kitchen Comedy Radio play, The Letter Box Rattles. Subsequently, the ex-surgeon wrote a series of theater plays with historical inspiration or, at least, nationalistic The Forrigan Reel (1944), Mr. Bolfry (based on the battle between good and evil is an occult drama written shortly after the loss of his son in the war-1943), melodrama Dr. Angelus (1947), and John Knox (1947) "a historical play about the reformation in Scotland" (4). The author also touches more modern themes in Daphne Laureola (1949), Mr. Gillie and The Queen's Comedy a year later, The Baikie Charivari or The Seven Prophets (1952). But what appears as a red thread in all physician's texts is the conflict between fault and fairness. The ambiguity of morality is the major theme in most of his plays. He raises questions but lets the characters evolve. With these, it persists in his writings a permanent doubt but his mark is the complex trait, with fast passes from austere to witty style: "a mixture of the serious with the jocular, the dignified with the ludicrous... he gave a sense of purpose to the Scottish theatre in the $20^{\text {th }}$ century" ( 3 ). One year after giving up his medical career, Bridie signed an autobiography, in 1939, One Way of Living "which gives the picture of a clever medical student and practicing doctor with a preference for literature" (1).

What characterizes Bridie's writing is a fine humor under whose crust are hidden generally valid truths, moral questions, the struggle between good and evil. His characters are either eccentric, or personae seeking their own identity, possessed by spe- 
cific human sins, those unadapted to the rules of society, make the journey of their lives in search of the essence. Here the influence of his medical studies can be perceived. The psychological deviation that he probably encountered in her medical career also gave him the subject of his dramas. Used to seeing the human beings suffering, degrading, during the years of war, nothing remains ransacked in the pages of this doctor-playwright: pride, hope, murder, illness, heredity. "As a physician Mavor was a true product of the Scottish tradition in Medicine - a skilled physician who knew his patients as individuals and treated them as such; a little distrustful of the so-called scientific approach and thankful if he could bring some comfort to the sick and ailing. To James Bridie also the individual was all important" (5).

His characters are, by definition, sick people whose moral sufferings are scrutinized by the author with detachment specific to the profession he practiced so many years. The one who decides about the vast majority of the endings is the reader. Bridie presents the case to the lecturer but does not offer solutions. The author seems to attribute himself only the role of unleashing the inner mechanisms of his characters without engaging in their inner life. This detachment from the painted characters is confirmed by the subtle humor the playwright uses. The author is interested in the mechanism of deviation, the moral confrontation that takes place in the characters' heart, but he does not arrogate the right to add, but only to make known the dramatic facts and to make the spectator an actor, for the lecturer is left in action and will judge alone. The anguish of the century in which he lived, the agitation of a society shaken by two wars, his own loss of his son will leave discrete traces in his texts. Even if, apparently, the author doses excellently joviality, this is a mere trick. The mental imbalance of the people just comes to highlight the deviation of the society that imposes often absurd rules. Most of Bridie's misfit characters have fallen out of their time, struggling with prejudices and outgrowing their lives.

The artistry of the author consists in the play of lights and shadows, from the contrasts that he creates not only in the atmosphere of the action but also in the characters' evolution. Very human, these characters resemble any of us, a mixture of good and evil, in different doses. The darkness of man's soul, inner conflict is what the author tries to transmit his reader. The goal of the playwright is not to educate the audience, but to stir them up, to ask themselves questions. Bridie's originality is that he incites the spectator who leaves the theater with much more questions than he came with.

That is why the author's conclusions do not seem clear because they are left to the listenerls discretion. The role of the playwright is just to awake up the unknown areas of the human soul, not to provide answers. His critics accused him of building unfinished characters, this alleged weakness, far from being a drawback, is precisely the strong point of the playwright. The sensation is that the author sets aside to let his characters come to life, their own life. He does not want to impose, but only presents, as a medical history, the facts. The diagnostician, this time, is the reader and his own consciousness. Letting the reins and allowing the characters to breathe freely shows the genius of this writer. The playwright just has the role of creating the frame, the place for the deeds and characters to unfold. He is a mediator, not an opinion former.

Ambiguity is natural, the conclusion is not important, but the unfolding of the events and the inner life of the characters, and Bridie is just an observer inviting spectators to join him. He only opens the door through the crack of which he allows the reader to see a new world, that of authentic experiences, without the mask imposed by everyday life. The innovating character of these dramas was not accepted by the exegetes to its true value. The main reproach brought to the author is of an unfinished fact, that he avoids placing himself on a certain position. But precisely what Bridie avoids is taking sides, he behaves like a perceiver not interfering in the nature of his characters. The vast majority of its characters are physicians who fight with a society reluctant at novelty, changing, or defensing old values. Shuffled by a society that does not accept the fact they are different, Bridie's characters are forced to live their fears, apprehension and hopes in their own intimidation. What all his pieces is pure humanity. Their drama goes to order the murders (The Anatomist) or to kill themselves (Dr. Angelus).

The playwright himself seems to be disappointed by the society, the institutions that represent it and the only way to save his characters is to make their own way. In fact, the initiatory journey is another favorite theme of the author (Tobias and the Angel). But his characters following their feelings, defying the rules imposed by a degrading society, these heroes are left guided by the inner self, and even if they seem to fail, they have the merit of remaining true to their own principles. More types of characters can be identified: the first are those who reject the domination on behalf of society, those 
who simply reject the rules or do not apply them. The second category of Bridie's characters are those who deviate from the norm and have different degrees of emotional dysfunction and the third category is those who are not only satisfied with a simple opposition to norm but go to destroying social values from within.

In fact, in the evolution of his characters we can see the author's emotional pathway. If his hope seemed intact in the period before World War II, his own disappointments change his tone, becoming more refractory to a society that is ill anyway. Bridie's heroes make very human decisions and assume them, and one of these assumptions is that they are aware of the discrepancy between themselves and society. Far from denying it, his characters accept the difference and have the sense of this individuality. The fact that the author decided to give up medicine and devote himself to writing is a form of revolt, and the trigger factor was the war and the horrors he lived. Returning to the peaceful life after the first conflagration, Bridie could not adapt to the quiet life of a general practitioner. The shock of those events he lived, the horrors seen would lead to the breaking of his own soul. It is what we would diagnose today as a post-traumatic shock, and the only way to get over the inner agitation, acting as a catharsis, was writing literature because the war had weakened him emotionally and had left the feeling of life uselessness. The help came from a friend, John Bradane, who presented himself to a theater band (Scottish National Players).

Written in 1937, Susannah and the Elders, resumes the theme within the Book of Daniel, apocryphal text. It is a play with religious references that discusses the problem of sin. Susannah is accused of cheating her husband by two elderly men because she had refused their indecent proposal. Daniel is the one investigating the case and an apparently minor detail makes beautiful Susannah escape the charge. The Baikie Charivari or The Seven Prophets (1952) is, as the author teaches us, situated between fantastic and real. The action takes place in a resort, Baikie Charivari, and Sir James MacArthur Pounce-Pellot is a military returned to Scotland after a long service in India. Three locals act as moral guides: Beadle-the priest is the spiritual guide, Mascara is the guide of aesthetic values and the female physician Pothecary who guides him emotionally. This seemingly peaceful group is one that glorifies Satan. The play is a concretization of the oldest preoccupation of the playwright represented by the struggle between man and evil in an attempt to save his soul. In fact, what the author thinks is that evil exists, he strongly believes in a personal devil, because we are all haunted by our own demons.

Another play with a character belonging to the medical field is Dr. Angelus (1949) and is based on a real fact: physician Edward William Pritchard (1825-1865) who was accused of killing his wife and his mother-in-law by poisoning, deeds for which he was hung. This was the last person to be executed in Glasgow. Daphne Aureola (1950) is the drama of a mature woman, Lady Katherine Pitts, married to an octogenarian, who finds her consolation in a relationship with a young Polish. The husband's death is followed by remarriage with the bodyguard, but not with the young man in question. The latter loses his temper. Daphne laureola is the name borne by a plant with a beautiful inflorescence but with poisonous fruits. This is a hint that the author did not even try to hide. It is an allusion to the poison good-looking flowers can have, just like human beings.

Mr Gillie (1950) is the case of a provincial teacher who, despite his own failures, tries to educate his students through literature. His belief in human goodness, in superior moral values even if they do not make him a hero in the classic sense, stir up the reader's sympathy. William Gillie is accidentally killed by the truck coming to take the furniture because the school he worked for is closing. Though a whole life he had devoted himself to inspiring others, he had not only failed but lost everything: home, school, and life. In essence, the piece asks the crucial question: how much we really do and what we are trying to do and the impression we leave behind. "O. H. Mayor's chief interest and study in life was his fellow men, not mankind in the abstract but men as individuals. These men or women might seem quite ordinary or even dull to other people, but Mavor always found something interesting or even unique in everyone he met" (6).

The sordid character of the society we live in is a leit-motif whenever possible. Bolfry's words best focus the author's perspective on the world, which, losing its true values, is drifting. Once the deviation occurs, the evil can take control of everything because it has no opponents anymore: "Your scientific gentlemen have robbed you of time and space, and you are all little blind semi-conscious creatures tossing about in a tempest of skim milk. If I may be allowed to say so, it all comes of thinking yourselves a little too good for your priests. You went prancing away from your churches and schoolrooms. And the first thing you did with your eman- 
cipated state was to hand yourselves over body and soul to a number of plain-clothes priests whose only qualification was that they were good at sums"
(7). In other words, the evil flourishes where the good does not oppose, acting against it.

\section{$\overline{\text { BIBLIOGRAFIE }}$}

1. Campbell I. Bridie James. Great Writers Library Twentieth Century Drama: Macmillan Press; 1983. p. 67.

2. Morgan E. James Bridie's The Anatomist and John Byrne's The Slab Boys. University of Strathclyde: Association for Scottish Literary Studies; 3 October 1987.

3. Royle T. Macmillan Companion to Scottish Literature. London: Macmillan Press; 1983.

4. Austin Mardon, Mardon E. The Conflict Between the Individual \& Society in the Plays of James Bridie. Canada: Golden Meteorite Press; 2012.

5. Osborne Henry Mavor-Obituary. Glasgow Medical Journal.32(6):202.

6. Osborne Henry Mavor-Obituary. Glasgow Medical Journal.32(6):203.

7. Bridie J. Mr. McCrimmon and the Devil. The Thistle and the pen An Anthology of Modern Scottish Writers, chosen and introduced by Eric Linklater: Nabu Press; 2010. p. 17. 